\title{
"Bringing a New Soul into Ireland": Literary Culture and Poetics of Orality in W. B. Yeats's Early Critical Writings
}

\begin{abstract}
The paper focuses on W. B. Yeats's idea of literary culture as it was theorised in his early essays and articles, with a particular attention directed to Ideas of Good and Evil and uncollected reviews spanning the last decade of the XIX century. It is argued here that Yeats projects his vision of a society as organised around poetic symbols that percolate down to the people like in ancient oral cultures. Instead of a politically-motivated and prejudiced nationalist ideology, Yeats proposes a religion of art that demands both a serious belief in the mystical insight conveyed by poetry and a constant questioning of this insight which is based on the notion that the true meaning of symbol cannot be fully understood. Thus Yeats's project of the literary culture is shown to have been pitched against the prevalent XIX century Irish nationalist dogmas that were promoted by old-school writers and political activists in the like of Charles Gavan Duffy.
\end{abstract}

Key words

Yeats; essay; cultural politics; Irish literature

W. B. Yeats has earned notoriety as a critic not only due to his often bizarre literary preferences but also, and that is especially true for his later writings, for his bellicose ideas. His stature as theoretician of poetry is marred, for reading his pronouncements on the nature of symbol and source of imagination involves deciding whether or not one credits the existence of magic and supernatural phenomena. However, Yeats's understanding of poetry is inextricably linked with his creative practice and, what is more, had he not pursued the thoughts delimited in his articles and essays, it is likely he would never have had the audacity to promote his ideas quite so formidably. In the present paper, I propose to investigate 
Yeats's earliest deployment of what in Autobiographies he referred to as "poetical culture" (1999: 118). It was in Ideas of Good and Evil (1903, henceforth cited in text as $I G E$ with page number) that Yeats for the first time brought together his various insights into the nature of literature and its role in the formation of what he believed would be a reinvented Irish nation. Set against other writings and ample correspondence of the period between 1890 and 1903 IGE reveals an unprecedented effort to make literature in general, and poetry and drama in particular, the foundation of a society of at once firm believers and ardent questioners of the religion of art.

$I G E$ comprises essays and articles written during a turbulent period in Yeats's generally tumultuous life. By the time the book appeared, he had already profoundly changed his understanding of poetry. While in May 1903, he commended $I G E$ as "thoughtful" in a letter to his American friend and impresario John Quinn, he also added, "I feel that much of it is out of my present mood. That it is true but no longer true for me [...] The book is, I think, too lyrical, too full of aspirations after remote things, too full of desires;" as opposed to the mellow theories promoted in IGE, Yeats announced to Quinn that "I will express myself so far as I express myself in criticism at all, by that sort of thought that leads straight to action, straight to some sort of craft" (1994: 372). In a letter to George Russell (AE), written a day before the one to Quinn, Yeats confessed, "I am no longer in much sympathy with an essay like the Autumn of the Body [...] The close of the last century was full of a strange desire to get out of form to get to some kind of disembodied beauty and now it seems to me the contrary impulse has come. I feel about me and in me an impulse to create form, to carry the realisation of beauty as far as possible" (1994: 369). Three years earlier he already doubted the reach of symbolism, confessing that "Now that I have had to read [Arthur] Symons book very carefully I have found it curiously vague in its philosophy" (2004: 506). Vagueness was among the hallmarks of Yeats's poetics in Symons's favourite The Wind among the Reeds but the turn of the century, "when everybody got down off his stilts" (1994a: 185), found Yeats far less amenable to dim landscapes where "the host is riding from Knocknarae / And over the grave of Clooth-na-bare" (Yeats 1996: 55). For now, as he told Lady Gregory, "My work has got far more masculine. It has more salt in it" (1994: 303). This aesthetic upheaval would soon bring Yeats to the directness and compactness that "Adam's Curse" first exemplified.

Despite its loss of currency after 1901, in IGE, Yeats deploys what would become his fundamental view of poetry and its role in the recreation of society. The collection was assembled and presented to Yeats's publisher A. H. Bullen in late 1901 as a replacement for the increasingly arduous novel The Speckled Bird, which Yeats never brought to completion. Bullen, who had already advanced Yeats a staggering sum of fifty pounds for The Speckled Bird, agreed to the deal and by April 1903 IGE had been released. The pieces collected date back to 1893, when he first came up with the idea of writing essays "dealing with Irish nationality an literature" initially to be entitled "Watch, Fire" (1970: 302). Fire indeed came aplenty in the decade between the first mention of the book and its actual 
publication, for it was at that time that Yeats fought out his first battles against what he considered to be the characteristically Irish bigotry, narrow-mindedness and provincialism.

Yeats's first major foray into the domain of cultural politics came with his cofoundation of the Irish Literary Society in London and the National Literary Society in Dublin. It was in his capacity as secretary of the Libraries Sub-Committee, within the frame of the NLS, that Yeats revived the 1845 Young Ireland idea of a library for the people. Back in 1845 the idea was that Irish people read too little and in order to tackle that problem a library of the most important titles should be founded, with select books being sold at the price of one shilling. To help him implement the new library for the people, Yeats made contact with Charles Gavan Duffy, a leader of the 1845 Young Ireland recently returned from Australia via France; with a hindsight Yeats realised that he "did not expect to agree with [Duffy], but knew that [he] must not seek a quarrel" at this precarious early stage (1999: 170), for he needed Duffy's connections and popular appeal as a patriot to underwrite Yeats's own project of a library for the people. Even though Yeats appreciated Duffy's influence and valour, he intimated that "the Young Ireland impulse seems to have died out and one is always on the watch for any sign of a new start," adding, "I imagine that it will be something more complex than any thing we have had in Ireland heretofore" (1986: 174). Recalling the quarrel in Autobiographies, Yeats, now able to be more generous, explains that "in all [of Duffy's] writings, there is so much honesty, so little rancour, there is not one sentence that has any meaning when separated from its place in argument or narrative, no one distinguished because of its thought or music" (1999: 186). Duffy was a paramount example of a political writer, just and honest but lacking imaginative flare, the very quality on which, according to Yeats, the future of the Irish literary culture depended.

By January 1892 the library scheme seemed to have been progressing well but as the year unravelled it became clear that Duffy had his own vision of what sort of literature people needed. Whereas Duffy believed in the openly patriotic writers and poets like himself and Thomas Davis, Yeats saw things in a more complex light. In a letter published in the United Ireland after the quarrel with Duffy erupted, Yeats asserted, "Let it be the work of the literary societies to teach to the writers on the hand, and to the readers on the other, that there is no nationality without literature, no literature without nationality" (1986: 299). He remained adamant in his opinion, for the same line was used already in 1890 in his article on Robert Browning for the Boston Pilot (1970a: 103-104). In June 1892, Yeats stated his agenda in no uncertain terms in the Daily Express, Dublin, noting that the projected titles for the library for the people "will be national but not political in any narrow sense of the word. They will endeavour to make the patriotism of the people who read them both deeper and more enlightened, and will set before them the national and legendary heroes as they present themselves to the minds of scholars and thinkers" (1986: 299-300). Yeats emphasises here his principal idea that literature is in no way related with politics but fosters people's imagination 
and intellect, allowing them to appreciate the complexity of the world. Duffy, on the other hand, sought books that would "make us wiser, manlier, more honest, and what is less than any of these, more prosperous. It is not the least of their merits that good books make manly men and patriotic citizens" (Duffy 17). These two positions proved irreconcilable and despite Yeats's tireless endeavours to outmanoeuvre Duffy, he suffered a defeat.

Struggles with Duffy showed to Yeats the importance of being able to coax people into accepting the ideas that they are being confronted with. This, however, meant a recourse to rhetoric, which Yeats condemned as "charm[ing] ears and dark[ening] understanding" (1986: 371). In his battle against the ossified ideas of patriotism based on unbreakable and uncritical subordination to the Irish cause, Yeats encountered a fit rival in one of Duffy's staunchest supporters John F. Taylor. Taylor excelled as orator and was no stranger to the art of libel. After initial praise for Yeats as a good writer and "Nationalist" (Taylor 1890: 23), Taylor came to "look at [him] with much hostility," which Yeats ascribed to Taylor's "jealousy of my favour in [John] O'Leary's eyes perhaps" (1999: 101), though Foster has suggested that this enmity may have partly been due to Taylor's "own obsession with a glamorous visitor to the Contemporary Club, the young and lovely Maud Gonne" (Foster 2008: 44), which seems plausible enough, given that discussing the struggle with Duffy and Taylor in Memoirs, Yeats admitted that at the time his "emotions were exasperated by jealousy, for everyone that came near Maud Gonne made me jealous" (1973: 65). Jealousy of Gonne or O'Leary notwithstanding, soon Taylor found reason enough to publically attack Yeats; the onslaught came for Yeats's defying Duffy. In two letters to The Freeman's Journal he sniggered at Yeats's idea of Irish literature, accusing him of "log-rolling" and conflict-mongering (Taylor 1892: 4, 1892a: 4). Yeats found those letters acrimonious and "contemptible" although his own response must have rung rather tepid (1986: 313). Rhetorical fire that Taylor unleashed against Yeats indicated that popular opinion was more likely to be swayed by high-pitched oration than poetic subtleties. However, Taylor also brought it home to Yeats "how great might be the effect of verse, spoken by a man almost rhythm-drunk, at some moment of intensity, the apex of long-mounting thought. Verses that seemed when one saw them upon the page flat and empty caught from that voice, whose beauty was half in its harsh strangeness, nobility of style" (1999: 103). It was not only the beauty of the poetic image that would capture people's imagination but also the delivery, although rhetorical impetuosity would soon be replaced by a subtler delivery more conducive to the ephemeral beauty of verse.

Taylor's attacks showed to Yeats that the dominant air of bigotry, intolerance and hate-obsessed partisan politics that he had already encountered after publishing his selections from William Carleton still ruled supreme in Ireland. Referring to a speech by Richard Ashe King at one of the NLS meetings in 1893, Yeats noted that "partisan politics laid waste" to "the Irish intellect" (1970: 306). Bearing in mind that he was bested by Taylor in the columns of The Freeman's Journal, Yeats - the quarrel with Taylor clearly on his mind - spared no rancour to the 
press, "newspapers become partisan when they give columns to some heated and trivial gentleman who is explaining that his opponent $[\ldots]$ is immensely deceitful and desperately wicked" (1986: 370). It was partisanship, bigotry and intolerance that were to pester Yeats throughout the decade, and indeed for the rest of his life. Most notably, he was badly hit at the time when his Countess Cathleen was to be staged. The play as it was known in its published form of Poems (1895) drew acrid criticism from a nationalist activist, Frank Hugh O'Donnell, who scolded Yeats for allegedly depicting Irish people as "abject-thieves and devil-worshippers" as well as promoting "the loathsome doctrine that faith and conscience can be bartered for a full belly and a full purse" (qtd. in Yeats 2004: 677). O'Donnell's pronouncement of The Countess Cathleen as full of "revolting blasphemies and idiotic impieties which sicken and astonish" brought the play to the attention and criticism of Cardinal Logue. Yeats retaliated by publishing a letter in the Morning Leader, repeating his well-known charge, "[Cardinal Logue's] reckless indignation is a part of that carelessness and indifference which the older generation in Ireland has too often shown in the discussion of intellectual issues" (2004: 410). Logue, having confessed that "All I know of this play is what I could gather from the extracts given in Mr. O'Donnell's pamphlet," went on to cast aspersions on The Countess Cathleen, stressing that all who watched it "must have degenerated, both in religion and patriotism" (qtd in Yeats 2004: 410). That sounded a sadly familiar note to Yeats, whose poetry and drama had repeatedly been charged with lack of patriotic feeling; still he saw a promising note in O'Donnell's attack, "I hardly think it will do us much harm. Everybody tells us we are going to have good audiences" (Yeats 2004: 403).

It was as early as July 1894 that Yeats first conceived of an idea to write "essays cheefly (sic) to be feirce (sic) mockery of most Irish men \& things except the men $\&$ things who are simple poor \& imaginative \& not I fear too many" (1986: 395). Although nothing came of it at the time, he would come back to the notion of bringing out a book of essays that would battle what he saw as Irish bigotry and intellectual laxity. ${ }^{1}$ In a letter published in the United Ireland in November 1894, he stated his critical and artistic credo: "The true ambition is to make criticism as international, and literature as National, as possible" (1986: 409). By this he meant that while literature grows strong only when it develops from the engagement with folklore, "from that contact everything Antaeus-like grew strong," as he wrote years later in "The Municipal Gallery Revisited" (1996: 321), criticism must necessarily look at national literature from the point of view of the accomplishment of the entire Western world. Thus he set the aesthetic standard very high, for unless Irish writers could rival the greatest artists in England and continental Europe, there was no hope that Ireland would ever progress beyond the level of a mere colony. In Autobiographies, Yeats adds that both the Catholic and the Protestant Ireland could be unified "if we had a national literature that made Ireland beautiful in the memory, and yet had been freed from provincialism by an exacting criticism, a European pose" (1999: 105). Thus for Yeats, nationalism as expressed in literature and criticism would "fight for moderation, dignity, 
$\&$ the rights of the intellect" (1986: 399). When in December 1892 Douglas Hyde unwittingly stabbed Yeats in the back by delivering his influential "The De-Anglicizing of Ireland," Yeats felt his favourite translator of Gaelic poetry missed the point. "Let us," Yeats wrote, "make [contemporary Irish writers'] books and the books of older writers known among the people and we will do more to deAnglicise Ireland than by longing to recall the Gaelic tongue and the snows of yester year;" rather than revive the language, Irish people should look to their eternal symbols instilled in mythology, which creative artists must express in the language they know best, for "it is [Cuchulain's] majesty and [Deirdre's] beauty which are immortal, and not the perishing tongue that first told of them" (1970: 256). Whatever Yeats's ulterior agenda may have been for speaking up against the revival of Gaelic, his central tenet was that of supreme artistry. No enforced change could alter people's minds, this task was vested solely in poetry.

Even in the articles and reviews published before or never included in $I G E$, Yeats kept returning to the idea that the function of poetry is to bring about an alteration in people's intellectual and social attitudes. The symbols evoked from the folk tradition by the poet establish a high ideal for people to follow and those symbolic characters are "sung out of the void by the harps of the great bardic order" (1970: 164). Poet as bard becomes a crucial figure for Yeats in that it was bards that conveyed the mystical symbols, that something "out of the world of thoughts into the world of deeds" (1970: 164). This idea remained central to Yeats's understanding of the function of poetry until his death. Poetry, as Yeats wrote in his important "Hopes and Fears for Irish Literature," is neither "an end it itself" nor an expression of "good life" (1970: 248-9), but "the principal voice of the conscience, and that it is its duty age after age to affirm its morality against the special moralities of clergymen and churches, and of kings and parliaments and peoples" (1994: 119). Yeats speaks here against the bigotry and unimaginative dogmatism as exemplified by O'Donnell and Logue, as well as scores of later critics of his art. However, his mutinous voice would only sound at full volume in $I G E$.

Despite its rather accidental genesis, the book was as assiduously structured as any other of Yeats's volumes. The arrangement of the essays belies the simple formula of collected papers in the sense that in IGE Yeats seeks to delineate a comprehensive vision of poetry that is opposed to the loud rhetoric of such critics as Taylor and simplistic moralisation of O'Donnell's type. In the first chapter, Yeats discusses two kinds of poetry, popular and unpopular. By the former he means writing "without care [...] but with a gusty energy that would put all straight if it came from the right heart" (2007: 6). Moreover, he adds that this popular poetry, which is the domain of such poets as for example Longfellow, Macaulay and Scott, is predominantly written by and for the middle class, "people who have unlearned the unwritten tradition which binds the unlettered, so long as they are masters of themselves, to the beginning of time and to the foundation of the world, and who have not learned the written tradition which has been established upon the unwritten" (2007: 7). As opposed to the popular 
written poetry, Yeats promotes the unwritten or oral poetry that is the domain of the common people. Thus already at the beginning he aligns himself with the tradition of oral poetry that dates all the way back to Homer, bypassing the writerly hegemony of the post-Renaissance western literature. As a result, it is the poet's physical voice that becomes the focus of lyrical composition. In the following chapter in $I G E$, Yeats discusses his early experiments with speaking to the psaltery, which at first he pursued with Florence Farr and never really gave up, as his friend Dorothy Wellesley recalled, "His last projective thought seems to me to be this wish for "words for melody"' (qtd. in Schuchard 2008: 401). Compared to "the gross effect" of modern "loud" acting, Yeats projects a new art of delivery that is "a monotony in external things for the sake of an interior variety, a sacrifice of gross effects to subtle effects, an asceticism of imagination" (2007: 16). Instead of flowery speech full of oratorical zeal, Yeats desires hushed delivery that will exude power through the sheer magnitude of rhythm of the words themselves. What he called "chaunting" is thus an attempt to retrieve the long-silenced tradition of oral poetry that sits at the centre of social consciousness. The major precedents for Yeats's experiment were mainly the Romantic poets, especially the young Wordsworth, but also the Victorians, particularly Tennyson and Swinburne (see Schuchard 2008: 10-12).

Rhythmical speaking of verse is designed to allow the ear to focus on the preternatural content of the sung symbol that eludes total comprehension. Having explicated the manner poetry should be delivered, Yeats goes on to discuss the source of the symbolic content, which he associates with magic. His understanding of magic is based on three doctrines, 1) that "borders of our mind are shifting, and that many minds can flow into one another;" 2) that "the borders of our memories are shifting, and that our memories are a part of one great memory;" 3 ) that "this great mind and great memory can be evoked by symbols" (2007: 25). This early formulation of what in the 1917 Per Amica Silentia Lunae Yeats would term Anima Mundi reveals that magic is in fact a province of poets, for it is in verse that the symbols which reside in the great memory can be clothed in language. Making magic a source of poetic symbols is here alluded to for the first time but magical intervention would prove instrumental in helping Yeats develop a new poetics when his wife revealed her gift for automatic writing. Moreover, given that all people have access to the great memory, the symbol, once sung in a poem, can gather people around the idea it expresses. In view of that fact, literature comes to people "as their own memories" (1994: 7) in that all symbols exist in the eternal repository of archetypes. Therefore Yeats suggests that all poetic novelty derives from symbols already thought out in this great storehouse. The future is written out in the past, just as the past exists for the sake of the future.

The abstruse veneer of magic notwithstanding, Yeats concludes that the social role of poetry is mandated by the fact that we all share in the great memory but only poets can find expression for the elusive symbols. Brown pertinently notes that Yeats "would expect poetry to serve as a handmaiden to magic, to transform a desacralized modernity, and make his native country (itself a repository of 
ancient magic) the heart of [...] spiritual rebirth, as the national culture awakened to spiritual life" (70). This awakening was to have been sparked by a poetic intervention. Discussing the role of memory in the formation of a community, Paul Zumthor explains that "As the performer joins his bodily presence with the poetic enunciation, his voice testifies to the social unity of a community. The poet comes from 'folk memory' that has nothing to do with folklore memories, but is ever correcting, changing and re-creating. Thanks to it, poetic discourse joins in the communal discourse, explaining and enhancing it" (Zumthor 2010: 155). In a similar vein, Walter J. Ong asserts that "primary orality ${ }^{2}$ fosters personality structures that in certain ways are more communal and externalized, and less introspective than those common among literates. Oral communication unites people in groups" (1993: 69). Thus "for Yeats the poetics of orality is also a politics, rejecting bourgeois individualism and the solitude of the study in the interests of public, communal experience" (Cullingford 1995: 114). When Yeats observes that "imagination divides us from mortality by the immortality of beauty, and binds us to each other by opening the secret doors of our hearts" (2007: 85), he seems to imply that poetry as the conveyor of the folk memory is the space of mutual participation in a collective act. In Yeats's "secondarily oral" society of poets and poetry readers, attending to the spoken poetic word becomes the key vehicle of verse, whereas the actual book, which Yeats always took pains to prepare as meticulously as he could, is an ancillary to the process of cultural edification.

However, Yeats remains slyly sceptical of the possibility of apprehending the complexity of the symbol. Although Brown is right in claiming that for Yeats, the symbol is "a magical formula, a potent image, an invocatory word, which is essentially related to the transcendent reality it evokes," he is too quick to assert that "there is nothing arbitrary about it" (73), as Yeats makes a point of eschewing such final pronouncements. In fact, symbols have neither an inherent nor arbitrary meaning $(2007: 39,85)$, for they are expressed in poetry only as "imperfection in a mirror of perfection, or perfection in a mirror of imperfection" (2007: 111). Thus despite the fact that they may contain the ideal thought, symbols, when they come down to the poet, become metaphors, and though they are "the most subtle, outside of pure sound" (2007: 115), they still escape analysis, possessing "the subtleties that have a new meaning every day" (2007: 120). R. B. Kershner comments on this centrifugal aspect of poetic speech, "the oral dimension of Yeats's writing points more directly to the untotalized, unfinalizable nature of speech, which always proceeds by modifying, defining, and interrupting itself in a linear chain without beginning of end" (186). However beautiful and subtle the language may be, Yeats maintains that it can only give a taste of the finite perfection of the symbol, a taste which is necessarily tinged by the bitterness of imperfection and incompleteness. Zumthor sees a similar structure of oral poetry. For him, the entire tradition of poetic speech can be understood as a collection of archetypes, whereas the current delivery is a variation on the archetype (Zumthor 160). Therefore the oral poet, whenever he performs before an audience, is instantiating an archetype but since his voice is distinct from the voices 
of the past poets, he also modifies the archetype through the medium of his art. An oral performance is thus a complex ritual that weds faith in the ideal thought comprised in the symbol with an ironic understanding that this thought is never to be given complete expression. Yeats summarises this twofold nature of poetry in a fine passage from the chapter devoted to Shelley, "The poet of essences and pure ideas must seek in the half-lights that glimmer from symbol to symbol as if to the ends of the earth, all that the epic and dramatic poet finds of mystery and shadow in the accidental circumstances of life" (2007: 66-67). Both the poet of essences and the dramatic poet, Yeats as he was before the turn of the centuries and after his involvement in the theatre, are thus wanderers among glimmers of shadows and accidental circumstances of life but it is only among those fragments that poets must seek eternal verities.

The society that would follow such poets, that would gather about the oral performer to listen to his or her subtle chaunting, must become like the small clique of theatre-goers, who keep their belief in "the noble art of oratory" (2007: 124) not that fervent declamation that Yeats associated with the "red-haired orator" John F. Taylor (2007: 126). "The theatre began in ritual, and it cannot come to its greatness again without recalling words to their ancient sovereignty" (2007: 125). In spite of the fact that even words brought to their ancient sovereignty cannot express the symbol fully, the community which Yeats was to refer to as possessing "poetical culture" must embrace poets as founders of collective consciousness as well as conscience. As he confesses in the final pages of IGE, "I would have Ireland recreate the ancient arts $[\ldots]$ as they were understood when they moved a whole people and not a few people who have grown up in a leisured class and made this understanding their business" (2007: 152). In IGE, Yeats, already entertaining the thought that his piece "will go into the book of essays rather well" (1994: 59), implies that the perfect society of cultivated people would resemble the community of bardolators who participated in the Shakespeare festival at Stratford in 1901. Importantly enough, Yeats regards Richard II as the true hero of all of Shakespeare's plays rather than Henry V. Whereas "[Henry V] has the gross vices, the coarse nerves, of one who is to rule among violent people, and he is so little 'too friendly' to his friends that he bundles them out of doors when their time is over," it is Richard, whose "mind like the jet of a fountain to fall again where it had risen," is possessed of "a resounding rhetoric that moves men" (2007: 81). For Yeats, Henry, an impetuous man, is a figure amply represented throughout Irish history, while Richard, the "vessel of porcelain," represents the subtle man of culture who knows that the power of contemplation surpasses the strength of immediate action. Therefore an entire society attending to the arts would accept the artist's vision not because it matches the prevalent morality of religious dogma but because it is expressed in a beautiful, moving and unhackneyed language that demands pondering. As Zumthor observes, "A text that is heard creates a communal consciousness just as language creates the society that speaks it" (Zumthor 175). In such a society, the poet becomes the legislator in that he or she organises social practices by providing a language in which people can 
identify, assess and eventually better understand themselves and others.

For all its practical bind, IGE proved too much for the Irish public, as Yeats himself predicted when he reminded Bullen "to send no copies of my books to Dublin papers. You did not send 'Celtic Twilight' \& it is still more desirable not to send 'Ideas of Good \& Evil'" (1994: 341). The only two reviews that appeared in Irish press proved critical to Yeats's endeavours. In the Irish Times, although he was praised for linguistic "craftsmanship," his general approach was deplored as lacking "dispassionate analysis and serene judgement which crystallise into the essay proper" (Anonymous 7). The Leader found still less to praise in IGE, mocking his spiritualism and denouncing him as a charlatan, who "could [not] tell if he really sees anything - and in any case it doesn't matter" (qtd. in Foster 294). In the United Irishman, John Eglinton, while agreeing with Yeats that the contemporary Irish society had become vulgar, pronounced Yeats's budding elitism "dangerous for mankind" (Eglinton 46). However, the path for Yeats lay with ever greater faith in the rule of the cultivated few. Still, the notion of poetical society that he elaborates on in $I G E$ survived the many changes that he went through over the years and returned to prominence in the idea of unity of being through unity of culture. In a later essay "If I Were Four-and-Twenty," Yeats ends on a sad note by observing what seems to have been the underlying premise of his critical and theoretical writings between the ages of the said twenty four and fifty four, when the above-mentioned essay was written, "if I were not four-and-fifty, with no settled habit but the writing of verse, rheumatic, indolent, discouraged, and about to move to the Far East, I would begin another epoch by recommending to the Nation a new doctrine, that of unity of being" (1994a: 46).

\section{Notes}

1 Yeats was close to collecting his Bookman articles in a single volume towards the end of 1895, when he contacted T. Fisher Unwin about the manuscript initially entitled "What to Read in Irish Literature" (Yeats 1986: 475).

2 Ong explains, "I style the orality of a culture totally untouched by any knowledge of writing or print, 'primary orality.' It is 'primary' by contrast with the 'secondary orality" of present-day high technology culture, in which a new orality is sustained by telephone, radio, television, and other electronic devices that depend for their existence and functioning on writing and print" (1993: 11).

\section{Acknowledgements}

The article has been written within the framework of the project financed by The National Science Centre, Cracow, Poland, pursuant to the decision number DEC-2013/09/D/HS2/02782. When completing the paper the author has been supported by the Foundation for Polish Science (FNP). 


\section{References}

Anonymous (1903) "Review of Ideas of Good and Evil." The Irish Times 22 May. 7.

Brown, Terrence (2001) The Life of W. B. Yeats: A Critical Biography. London: Blackwell.

Cullingford, Eizabeth Butler (1995) "The Erotics of the Ballad: "A Man Young and Old"'. In: Liebregts Peter and Peter van de Kamp (eds.) Tumult of Images. Essays on W. B. Yeats and Politics. Amsterdam and Atlanta: Rodopi, 109-130.

Duffy, Charles Gavan (1893) "What Irishmen May Do for Irish Literature." In: Duffy, Charles Gavan (ed.) The Revival of Irish Literature. Two Addresses. London, 9-33.

Eglinton, John (1917) Anglo-Irish Essays. London: Talbot Press.

Foster, R. F. (2008) W. B. Yeats: A Life, I: The Apprentice Mage. Oxford: Oxford University Press.

Kershner, R. B. (1991) "Yeats/Bakhtin/Orality/Dyslexia." In: Orr, Leonard (ed.) Yeats and Postmodernism. Syracuse: Syracuse University Press, 167-188.

Ong, Walter J. (1993) Orality and Literacy. The Technologizing of the Word. London and New York: Routledge.

Schuchard, Ronald (2008) The Last Minstrels. Yeats and the Revival of Bardic Arts. Oxford: Oxfrod University Press.

Taylor, John F. (1890) "The Literary Movement in Ireland." The United Irishman.

Taylor, John F. (1892) "Letter to the Editor." The Freeman's Journal 7 September. 4.

Taylor, John F. (1892a) "Letter to the Editor." The Freeman's Journal 9 September. 4

Taylor, John F. (1897) The Irish School of Oratory, 664-675.

Yeats, W. B. (1970) Uncollected Prose. Volume I. Ed. John P. Frayne. New York: Columbia University Press.

Yeats, W. B. (1970a) Letters to the New Island. Ed. Horace Reynolds. Cambridge MASS: Harvard University Press.

Yeats, W. B. (1973) Memoirs: Autobiography_First Draft: Journal. Ed. Denis Donoghue. London: Macmillan.

Yeats, W. B. (1986) The Collected Letters of W. B. Yeats. Volume I. Eds. John Kelly and Eric Domville. Oxford: Clarendon Press.

Yeats, W. B. (1994) The Collected Letters of W. B. Yeats. Volume III. Eds. John Kelly and Ronald Schuchard. Oxford: Clarendon Press.

Yeats, W. B. (1994a) The Collected Works of W. B. Yeats: Volume V, Later Essays. Ed. William H. O'Donnell. New York: Scribner.

Yeats, W. B. (1996) The Collected Poems of W. B. Yeats. Ed. Richard J. Finneran. New York: Scribner.

Yeats, W. B. (1999) The Collected Works of W. B. Yeats: Volume III, Autobiographies. Ed. William H. O'Donnell and Douglas N. Archibald. New York: Scribner.

Yeats, W. B. (2004) The Collected Letters of W. B. Yeats. Volume II. Eds. Warwick Gould, John Kelly and Deirdre Toomey. Oxford: Clarendon Press.

Yeats, W. B. (2007) The Collected Works of W. B. Yeats: Volume IV, Early Essays. Ed. Richard J. Finneran and George Bornstein. New York: Scribner.

Zumthor, Paul (2010) "Pamięć i wspólnota." Literatura ustna. Trans. M. Abramowicz. Ed. Przemysław Czapliński. Gdańsk: słowo/obraz terytoria, 151-179.

Wit Pietrzak is Assistant Professor of English Literature in the Institute of English Studies, Faculty of Philology, University of Łódź. He teaches British literature and theory of literature, specialises in the English and Anglo-Irish poetry of the modernist period as well as contemporary English-language poetry. He is the author of Myth, Language and Tradition. A Study of Yeats, Stevens and Eliot in the Context of Heidegger's Search for Being (2011), Levity of Design. Man and Modernity 
in the Poetry of J. H. Prynne (2012), Życie po życiu (Life after death, 2012) and Ostrożnie, poezja! Szkice o wspótczesnej poezji anglojęzyczej (to be published in 2015).

Address: dr Wit Pietrzak, Institute of English Studies, University of Łódź, Pomorska 171/173, 90236 Łódź, Poland. [witpietrzak@wp.pl] 